\title{
II Macrothink

\section{Testify to the Wilayah in Azan and an Eghame from the perspective of the five religions}

\author{
Sedigheh Mosadegh Sedghi (Ph.D) (Corresponding author) \\ Department of Religious Jurisprudence and Islamic law, Karaj branch, Islamic Azad \\ University, Karaj, Iran Tel: +989123965831Ｅ-mail: mosaddegh_sedghi@yahoo.com
}

\begin{abstract}
Zahra Moghari (M.A)
Department of Religious Jurisprudence and Islamic law, Karaj branch, Islamic Azad University, Karaj, Iran
\end{abstract}

Accepted: May 24, 2013 Published: June 26, 2013

Doi:10.5296/ijld.v3i3.3920ＵRL: http://dx.doi.org/10.5296/ijld.v3i3.3920

\begin{abstract}
Azan is a means to declare, and collect the Muslims to prayer and say it in a prayer congregation of greater emphasis. With regard to the matter in the sayings and traditions about Azan and Eghame is mentioned the question arises why between Islamic schools in conjunction with the outlines and even chapters of Azan and Eghame all this controversy is there?

One of these disputes to the problem of the Leadership and supervision (wilayah) Ali (a.s) in Azan and Eghame Shiite; Sunni opinion this chapter is not part of the original seasons of Azan and Eghame and entering it in the Azan and Eghame is considered a kind of heresy. But the Shiite belief to enter this season without the intention of obligatory. The existence of these differences led to research in this area by examining the sources of juridical and validity of religions to solve ambiguities.
\end{abstract}

Key words: Azan; Eghame; Chapters of Azan and Eghame; Shiite; Sunni; Testify to Leadership

\section{Introduction}

\section{The meaning of testify to the Leadership and supervision (wilayah)}

The testify the promise of science, that the man of science, into something that speaks to a theorem; it would have seen it and testify to it or with reason and argument to find the certainty and knowledge and testify; as testify to the divinity of the Almighty God and prophecy and the Imamate and the resurrection.

The Leadership and supervision (wilayah), namely Imamate and administration but to capture, the meaning of the Leadership and supervision (wilayah), Ali (as), namely the belief supervision Bella distance of the Imam Ali (a.s) on people after the Prophet (s.a.w).' 
Muezzin in your Leadership and supervision (wilayah) to witness the Azan Ali (as), with the intention of a consecration that people! Ali Ibn Abi Talib (as) someone who is Imam and Caliph after the Prophet to capture people's Governor, and the Leadership and supervision (wilayah) Ali (as) is also upon us. (Rezvani,2008).

\section{In testify to the judgment of Azan and Eghame}

(Testify of tertiary) means the Leadership and supervision (wilayah) Ali (peace be upon him) after the testify of the Prophet's mission to in Azan and Eghame, there is another of the issues, some say because the narratives to testify to the mentioned Leadership and supervision (wilayah) and Shi Imamie in the meantime the Azan, seasons so it was his act heresy and certainly is wrong.

But the Shia belief Imamie this action not only can be, but his innovation and according to obligatory and it includes even so some caution is mentioned in it, but that's all in the possibility, with the intention of going to the component in the component or lack of Azan and Eghame, for which it is not the intention to bring a mere component of the beatification and to lick there in reverence and heresy and it doesn't. (Rezvani,2008).

\section{No permission mentioned the testify of tertiary person to the component}

The testify of religious beliefs is part of the Leadership and supervision (wilayah), to Imamie but is not a component of Azan and Eghame, and say it has no intention of component I strong and obligatory, i.e. a greater emphasis (Gulpaygani Moses, 1990).

Whenever someone after the vacuum of the testify on the mission say "by Ann Olya Amir almomneen» to the position of this Hadith is not the intention that precautionary action, part of his prayer. (Gilani Shfati,1990).

After the testify is not part of the Leadership and supervision (wilayah) of Azan and Eghame is good but it is the intention of closeness to God(Lankaran,2004).

So we see that all the attention to this point scholars have Imamie who should testify in the mentioned component is going to Azan or else innovation: the first martyr in this case says: "to the Leadership and supervision (wilayah) Ali (a.s.) and "That Ali Wali Allah and Muhammad the best land" is one of the tenets of faith, not of words Azan" (Amoli,1998).

The first Majlesi also said: "appearance of it is that if someone is telling testify to the Leadership and supervision (wilayah) in the Azan alright unless its sharait with the drive to be the first error and that it is faith that is part of the faith tell it, not the intentions that the component Azan" (Esfahani,1987).

Researcher Sabzevari says:

"The companions have reiterated that add "That Ali Wali Allah and Muhammad the best land" and so this sentence is in the Azan heresy, although the word is right and correct per se limit because, Existence is talk that of it in Azan Stop Sharia (legal), which have not been proved." (Sabzwari,1828).

The second Majlesi is brought:

"If someone in the Azan and a Eghame tertiary testify without going to the component, but the intentions of the beatification say alright, because speaking Meanwhile Azan and Eghame and administered the Leadership and supervision (wilayah) most of Sharif's testify to prayer and mention (Esfahani (Second Majlesi), 2000).

Behbahani says: 
Mentioned "Mohammed and His inmate the best of creatures" and I bear witness that Ali Waliullah" in prayer with the intention of entering the Unlawful component and is not intended to single verb.

Following the testify of religious beliefs is part of the Leadership and supervision (wilayah) to Imamie, but is not a component of Azan and Eghame, and saying it has no intention of component I, and saying without intention particularity, it is the reward, And recommended is emphatically (Gulpaygani Moses,1990).

Recommended being tertiary testify, without intention particularity

Imami clerics, do not permissible, testify of cite intention the tertiary being Inside, but agree that telling it in Azan, after the testify of the Prophet Mohammad (SAW), Without intention being Inside, only intention consecration no quotes needed, It is recommendable; And precaution is obligatory.

Allameh majlesi: Not unlikely that testify be Recommended to the wilayah component of Azan. (Esfahani (Second Majlesi,2000).

Sayed Ali Tabatabai also said: Some narratives testify to the wilayah Is recommended after testimony to Prophet Muhammad (SAW) (Tabatabai, 2002).

\section{Recommended being testimony to wilayah}

Seems to be the testify of tertiary can be proved via:

A) Specific narratives that testify to in Azan refers to wilayah.

B) Narratives public refers to on recommended rule regarding the implementation of the general case.

C) Prove the Leadership and supervision (wilayah) Amir almomneen (as) of (verse 55 Sura maedeh).

There are specific traditions and general about it, we do not tell them that because of the long, You can see to source(Tabarsi,1984);( Rezvani,2008); (Esfahani (Second Majlesi),2000).

O you who believe OR who believe «Al-lazina Amano» in Sunni books

Numerous traditions have been narrated in many Sunni sources To emphasize ,Surat Maedeh verse 55, which has been revealed to Hazrat Ali (AS). has been quoted as revealed in some of them refer to Forgiveness his ring, while bowing., and in some only to sink the verse about Ali (as) has been satisfactory. In relation to the mean (O you who believe), Ali (AS) is, we have several traditions (Makarem Shirazi,1997);( Al-hndi, Alaeddin, 1998).

\section{Negligently rule, in traditional reasons}

Has been demonstrated in principles of jurisprudence, for recommended sentence need not be valid reason conclusive. And traditions that the document is poor can be recommended in sentence to be invoked(Rezvani,2008).

Deceased Qummi says:

Can be understood from the words of the great scholars, There are traditions that the tertiary testify; Namely, Ali Love of God is located after testify to Prophet Muhammad. And this is reasons order to And Negligently in the narrative(Gilani ,1998). 


\section{Conclusion}

1-In relation to the question of testify to the Leadership and supervision (wilayah) in the Azan is also citing the narrations and mentioned the fatwa was that telling Imamie "I bear witness that Ali Waliulla." in Azan if it is not the intention of the component and with the intention of consecration is noteworthy, not only alright, but it is obligatory as well.

2-With a look at the reasons for this was that determined, firstly, on the basis of the existing of the Shiite fatwa- testify tertiary intention component in Azan and Eghame does not say, and according to this, one of the pillars of innovation and practical religion is to be imported, after the component mentioned is not considered heresy.

3- Saying, this except (I testify Ali is friend of God) without intention being Inside is recommended, and for this reason heretical is out of the title.

\section{Acknowledgement}

Friends who have helped me in writing this paper am grateful, as well as the parents.

\section{References}

\section{References}

***The Holy Quran

1. Esfahani, Mohammad Taghi, Rovzht Al-motqin, publisher: Koshanpor Culture and Art Institute, Qom, Iran, V 2, p 246.

2. Esfahani (Second Majlesi), Mohammad Bagher,, Bihar al-Anwar, Institute published in Beirut, Lebanon, 2000, V 81, p 112;V16,P368.

3. Rezvani, Ali Asghar, comparative jurisprudence, Publisher: Dhu al-Qirbi, Qom, 2008, pp. 146-155.

4. Sabzwari, Mohammad Bagher, bring Al-mad fi described Al-arshad (Recycled ammunition in the explanation of Al-ershad), Al-Bayt Institute, Qom, Iran, 1828, V 1, p 254.

5. Tabatabai,Seyd Ali, Riyadh Al-masaeel(Rulings of Taqlid), Publisher: Al-Bayt Institute, Qom, 2002, V 3, p 98.

6. Tabarsi, Ahmed bin Ali, Al-ahtyaj, publishing: Morteza, Mashhad, Iran, 1984, V 1, p 228.

7. Ameli (the first martyr) Muhammad ibn Makki, Al-dorvs, Islamic published Office affiliated to the comprehensive instructor, the seminary of Qom, Qom, Iran, 1998, V $1, \mathrm{p} 162$.

8. Gulpaygani Moses, Seyed Mohammad Reza, set the catechism(Rulings of Taqlid), Dar Al-Quran al-Karim, Qom, Iran, 1990, V 4, p 100.

9. Gilani Shfati, Sayed Muhammad Baqir, Tohfat Abrar, Publication: Library of Masjed Soleiman, Isfahan, Iran, 1990, Vol 1, p 431.

10. Gilani , Mirza Qummi qanaem Al-ayam Fi matters Al-halal and Al-haram, published: Islamic Propagation Office, seminary school, Qom, Iran, 1998, V 2, p 423.

11. Lankaran, Mohammad Fazel, comprehensive catechism(Rulings of Taqlid), published: Amir Qalam, Qom, Iran, 2004, V 2, p 124. 
12. Makarem Shirazi, Nasser, Examples interpretation (Tafsir Nemone), Dar al-katb al-islami, Tehran, 1997, V 4, p 424.

13. Al-hndi, Alaeddin, Kanz Al-emal, Dar Al-ketab Al-elmiht, Beirut, 1998, V 13, p 108 